\title{
Photoadaptation of sea-ice microalgae in springtime: photosynthesis and carboxylating enzymes*
}

\author{
${\text { Christine } \text { Michel }^{1} \text {, Louis Legendre }}^{1}$, Serge Demers ${ }^{2}$, Jean-Claude Therriault ${ }^{2}$ \\ ${ }^{1}$ Département de biologie, Université Laval, Québec, Canada G1K 7 P4 \\ ${ }^{2}$ Institut Maurice-Lamontagne, Ministère des Pêches et Océans, C.P. 1000, Mont-Joli, Québec, Canada G5H 3Z4
}

\begin{abstract}
Photoadaptive responses of sea-ice microalgae in springtime were observed in southeastern Hudson Bay (Canadian Arctic). The responses included changes in pigment composition (chlorophyll $a$, carotenoids), photosynthetic parameters ( $\operatorname{Pmax}, 1 k, \alpha, \beta$ ) and carboxylating enzymes. The complete transition from shade to light adaptation took place over 1 generation time while susceptibility to photoinhibition decreased more rapidly. Activities of carboxylating enzymes were never the ratelimiting step of photosynthesis. At low irradiances, increased pigments in the cells and modifications of the photosynthetic parameters suggest that photosynthesis did depend on the trapping of light energy and on the rate of electron transport. With increased irradiances, light energy harvested by the cells exceeded their energetic requirements, so that photosynthesis was only related to the rate of electron transport. These results emphasize the ability of sea-ice microalgae to photoadapt to the seasonally increasing under-ice irradiance, showing that they are not an obligate shade flora in southeastern Hudson Bay.
\end{abstract}

\section{INTRODUCTION}

The successful development of microalgae in polar waters, under conditions of very low light and temperature, has been the subject of several studies in the past few decades (e.g. Appolonio 1961, 1965, Bunt 1968, Neori \& Holm-Hansen 1982, Jacques 1983, Cota 1985, Palmisano et al. 1987).

Light has been identified as a critical factor for the growth of ice algae (Meguro et al. 1967, Bunt \& Lee 1970. Horner \& Schrader 1982). The investigations of Cota (1985) in the High Arctic and of Palmisano et al. (1985) in the Antarctic have suggested that ice algae are markedly shade-adapted. On the other hand, Gosselin et al. (1985), Rochet et al. (1986) and Barlow et al. (1988) found that ice algae in Hudson Bay were not an obligate shade flora, and that they adapted to the seasonally increasing irradiance. In Hudson Bay, Gosselin et al. (1985) have reported a critical value of 7.6 uEin $\mathrm{m}^{-2} \mathrm{~s}^{-1}$ below which there was no population

\footnotetext{
- Contribution to the programs of GIROQ (Groupe interuniversitaire de recherches océanographiques du Québec) and of the Maurice-Lamontagne Institute (Department of Fisheries and Oceans)
}

growth. At higher light intensities (up to $9.0 \mu$ Ein $\mathrm{m}^{-2} \mathrm{~s}^{-1}$ ) ice algae seem to photoadapt by improving the trapping of light energy and simultaneously increasing the density of reaction centers of photosystem I (RCI) and that of plastoquinones; above $9.0 \mu \mathrm{Ein} \mathrm{m}^{-2} \mathrm{~s}^{-1}$ the density of reaction centers and plastoquinones is reduced but electron transport through $\mathrm{RCI}$ becomes faster (Barlow et al. 1988).

In addition to modifications in the photosynthetic apparatus itself (size and number of photosynthetic units, electron transport components), the photoadaptive strategies of algae could also involve changes in activities of photosynthetic enzymes (Steemann Nielsen \& Hansen 1959, Beardall \& Morris 1976, Falkowski \& Owens 1980). For higher plants, Berry \& Björkman (1980) and Berry \& Raison (1981) have shown that photosynthesis depends on electron transport capacity when temperature conditions are optimal; at suboptimal temperatures, photosynthesis is likely to be limited by enzyme reactions. Considering the very low temperatures prevaling in polar waters, carboxylating reactions can be expected to limit photosynthesis.

This paper describes the succession of photoadaptive events experienced by microalgae at the ice-water interface during the springtime in southeastern Hud- 
son Bay. Observations concern changes in carboxylating enzymes and photosynthetic parameters, which allows assessment of the relative importance of enzyme reactions versus electron transport in limiting the photosynthetic capacity of these algae. Moreover, since activities of 3 carboxylating enzymes (RuBPC, PePC and $\mathrm{PePCk}$ ) were measured, the contribution of $\beta$ carboxylation relative to $\mathrm{C}_{3}$-carboxylation can be estimated for a natural population of ice microalgae.

\section{MATERIALS AND METHODS}

Sampling was conducted from 3 April to 15 May 1986 , on the first-year ice of Hudson Bay $\left(55^{\circ} 30.1^{\prime} \mathrm{N}\right.$, $77^{\circ} 44.9^{\prime}$ W) $22 \mathrm{~km}$ off Kuujjuarapik (Fig. 1). Every second day, free-floating ice algae at the ice-water interface were collected by SCUBA divers using a 2 l syringe sampler. These were rapidly brought to a shore laboratory in Kuujjuarapik for further analyses. The samples did not contain ice. Under-ice irradiance at the interface was measured with a scalar irradiance meter moored at the ice-water interface (Biospherical MER 1010), and temperature and salinity were recorded with a guildline CTD probe.

Microalgae were filtered on $2.5 \mathrm{~cm}$ Whatman GF/F glass-fiber filters, for the spectrophotometric determination of chlorophyll $a$ and carotenoid pigments after $24 \mathrm{~h}$ extraction in $90 \%$ acetone at $5{ }^{\circ} \mathrm{C}$, using the equations of Jeffrey \& Humphrey (1975). Cell identification and enumeration were done with an inverted micro-

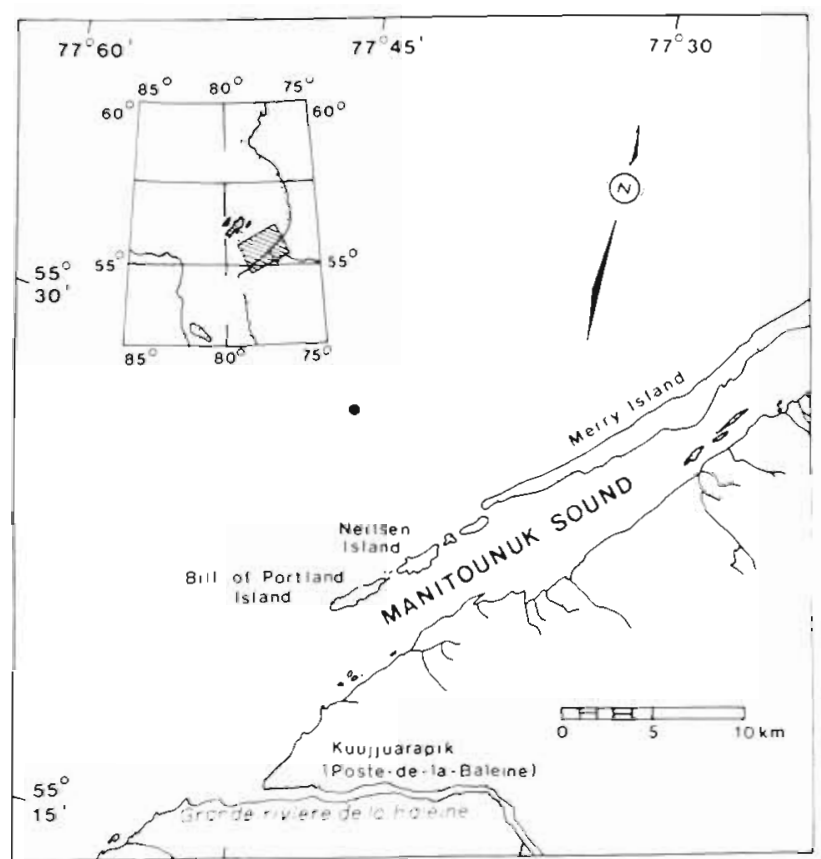

Fig. 1. Location of the sampling station off Kuujuarapik in Southeastern Hudson Bay scope (Lund et al. 1958) on samples preserved in acidic Lugol.

Beginning on 9 April, photosynthesis was measured on $251-\mathrm{ml}$ aliquots, each one inoculated with $1 \mu \mathrm{Ci}$ $\mathrm{NaH}^{14} \mathrm{CO}_{3}$ and incubated for 20 min under different irradiances, as described by Lewis \& Smith (1983). Incubations were performed at $-1.5^{\circ} \mathrm{C}$ and under bluegreen light, in order to simulate the under-ice light conditions (Maykut \& Grenfell 1975). Incubations were conducted at the same temperature throughout the season, as temperature at the ice-water interface remained very constant $\left(x=-1.3^{\circ} \mathrm{C}, \mathrm{s}=0.18\right)$, except for the last $2 \mathrm{~d}$ of biological sampling (Fig. 2). At the end of incubations, $0.5 \mathrm{ml} 6 \mathrm{~N} \mathrm{HCl}$ was added to each sample and excess ${ }^{14} \mathrm{C}$ was evaporated during $40 \mathrm{~min}$. After evaporation, $12 \mathrm{ml}$ of an Aquasol-methanol mixture (10:1 vol:vol) were added to the samples, which had been neutralised with $0.5 \mathrm{ml} 6 \mathrm{~N} \mathrm{NaOH}$. Samples, stored in the dark, were counted on a LKB WALLACK scintillation spectrometer (Mini Beta Model 1211), using the channels radio method. Parameters of the photosynthesis versus irradiance curves were estimated according to the model of Platt et al. (1980). These are the maximum photosynthetic rate (Pmax), the slope of the initial portion of the curve $(\alpha)$, the slope of the inhibited portion of the curve $(\beta)$, and Ik = Pmax/ $\alpha$, the photoadaptive index described by Talling (1957). For each curve, the initial activity of the ${ }^{14} \mathrm{C}$ solution was estimated, and there were 2 controls treated with DCMU (Legendre et al. 1983) which is known to block electron transport near photosystem II.

Activities of RuBPC, PePC and PePCk were determined using the ${ }^{14} \mathrm{C}$ technique described by Smith et al. (1983) and modified by Li et al. (1984). Similar enzyme assays have been carried out in other laboratories (e.g. Storrø \& McFadden 1983). For each sample, 5 aliquots of seawater, including 2 blanks, were filtered on $2.5 \mathrm{~cm}$ Whatman GF/F filters. Volumes filtered varied during the sampling season, according to the concentration of algae at the ice-water interface. In early April, $100 \mathrm{ml}$ of sea water were filtered, while in May when chlorophyll a concentrations were maximum, only $20 \mathrm{ml}$ were filtered. The filters were rinsed with a solution made of Tris buffer $(0.1 M, \mathrm{pH} 7.5)$, $\mathrm{MgCl}_{2} \cdot 6 \mathrm{H}_{2} \mathrm{O}(20 \mathrm{mM})$. EDTA $(0.78 \mathrm{mM})$, reduced glutathione $(10 \mathrm{mM})$, dithiothreitiol (DTT) (5 mM), $\mathrm{NaHCO}_{3}(25 \mathrm{mM}$ ) and $\alpha$-lysophosphatidylcholin 10.2 $\mathrm{mgl}^{-1}$ ) (Miller et al. 1978, 1979). In PePCk assays, $\mathrm{MgCl}_{2} \cdot 6 \mathrm{H}_{2} \mathrm{O}$ was replaced by $\mathrm{MnCl}_{2} \cdot 4 \mathrm{H}_{2} \mathrm{O}(2 \mathrm{mM})$, and $\mathrm{ADP}(5 \mathrm{~m} M)$ was added to the solution. Each filter, placed in $1 \mathrm{ml}$ of this solution made to $1.5 \mathrm{M}$ with glycerol (Syrett 1973), was preincubated at $0^{\circ} \mathrm{C}$ during $40 \mathrm{~min}$. At the end of the preincubation, the filters received $100 \mu \mathrm{l}$ of the rinse solution to which were added $2 \mathrm{mg}$ of RuBP $\left(\mathrm{Na}_{4}\right.$ salt, Sigma) for the RuBPC 
assays, and $5 \mathrm{mg}$ of $\mathrm{PeP}\left(\mathrm{Na}_{3}\right.$ salt, Sigma) for the PePC and PePCk assays. Blanks received the rinse solution without reagents. After 3 additional minutes of preincubation, the samples were inoculated with $\mathrm{NaH}^{14} \mathrm{CO}_{3}$ $(100 \mu \mathrm{l}, 5 \mu \mathrm{Ci})$ and incubated at $20^{\circ} \mathrm{C}$ for $40 \mathrm{~min}$. This temperature is adequate for enzyme activities according to the results of $\mathrm{Li}$ et al. (1984) for 3 carboxylating enzymes in Arctic phytoplankton, and Descoslas-Gros \& De Billy (1987) and Smith \& Platt (1985) for RuBPC in respectively cultures of Antarctic diatoms and Arctic phytoplankton. The reaction was stopped by the addition of $0.5 \mathrm{ml} 6 \mathrm{~N} \mathrm{HCl}$. Evaporation, neutralisation with $6 \mathrm{~N} \mathrm{NaOH}$, and counting of samples were the same as for photosynthesis.

Physiological parameters were normalized to unit chlorophyll a and to cellular volume. Total cellular volumes were estimated using average cell volumes, measured for the most abundant species, together with the numbers of enumerated cells (Smayda 1978). Normalizing physiological parameters to unit cellular volume is the logical approach for natural populations, even if it is relatively time consuming. With laboratory cultures, physiological parameters can be normalized to unit cell, but this is not possible with natural populations in which cell sizes are distributed over wide ranges. In this paper, parameters normalized to cellular volume and to chlorophyll a are respectively identified by $v$ or $b$, as for example $\mathrm{P}^{\mathrm{v}} \max$ and $\mathrm{P}^{\mathrm{b}} \max$.

In order to facilitate visual interpretation of data, moving averages were drawn on figures showing time series. However, results reported below were computed on the original data, not the moving averages.

\section{RESULTS}

Average irradiance under the ice was $4.0 \mu$ Ein $\mathrm{m}^{-2} \mathrm{~s}^{-1}(\mathrm{~s}=1.0)$ before 25 April, after which it rapidly increased to an average of $17.9 \mu \mathrm{Ein} \mathrm{m}^{-2} \mathrm{~s}^{-1}(\mathrm{~s}=7.3)$ (Fig. 2A). Temperature and salinity at $0.5 \mathrm{~m}$ under the ice were quite stable until 12 May $\left(\mathrm{T}=-1.3^{\circ} \mathrm{C}, \mathrm{S}=27\right)$, after which there was a slight increase in temperature (to $0^{\circ} \mathrm{C}$ ) and an important decrease in salinity (to 7 ) (Fig. 2B, C). Under-ice irradiance was related to the thickness of the snow cover; the rapid increase of under-ice irradiance after 25 April corresponded to snow melt and the decrease that occurred from 1 to 7 May was associated with a snowfall (Fig. 2A, D). Changes in water salinity and temperature after 12 May were associated with ice melt (Fig. 2B, C, E)

During the sampling period, chlorophyll a concentration of ice-algae collected at the ice-water interface (Fig. 3A) increased from $0.8 \mathrm{mg} \mathrm{m}^{-2}$ to a maximum of $23.6 \mathrm{mg} \mathrm{m}^{-2}$; at the time of ice melt (15 May), cells were
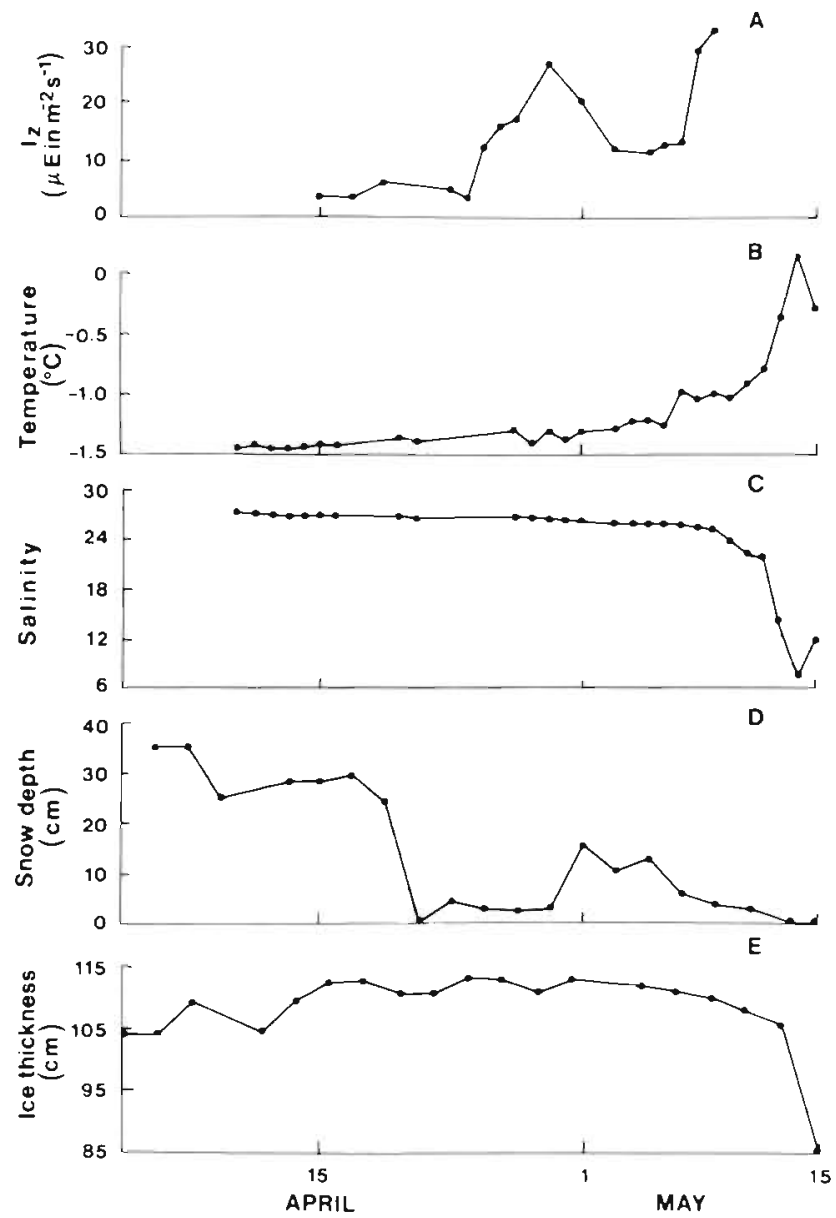

Fig. 2. Seasonal variations of (A) under-ice irradiance, (B) water temperature, (C) salinity, (D) snow depth, and (E) ice thickness

flushed from the interface, and chlorophyll a dropped to $0.6 \mathrm{mg} \mathrm{m}^{-2}$. Cell numbers varied in correlation with chlorophyll a $(r=0.94, p<0.01)$, reaching a maximum value of $5.8 \times 10^{9}$ cells $\mathrm{m}^{-2}$ on 12 May (Fig. 3B). Changes in total cellular volume (Fig. 3C) followed the seasonal trend already noted for chlorophyll $a$ and cell numbers (Fig. 3A, B). The ice-algal community was numerically dominated by Nitzschia frigida (41\%), followed by Navicula pelagica $(14 \%), 2$ unidentified species of Nitzschia $(14 \%)$, flagellates $(14 \%)$ and Chaetoceros spp. (5.1\%) (Fig. 4). Fig. 5A shows the seasonal decrease of chlorophyll a normalized to unit cellular volume. Carotenoids followed a similar trend as chlorophylla (Fig. 5B), but the ratio carotenoids: chlorophyll a increased slowly from around 21 April (Fig. 5C).

Fig. 6 shows the variations of photosynthetic paramters Pmax, $\alpha, \beta$, and Ik. $\mathrm{P}^{\mathrm{b}}$ max increased rapidly after the beginning of May (Fig. 6A), this increase being correlated with a $4 \mathrm{~d}$ lag to the under-ice irradiance Iz $(r=0.80, p<0.01)$. The same lag-correlation was found 

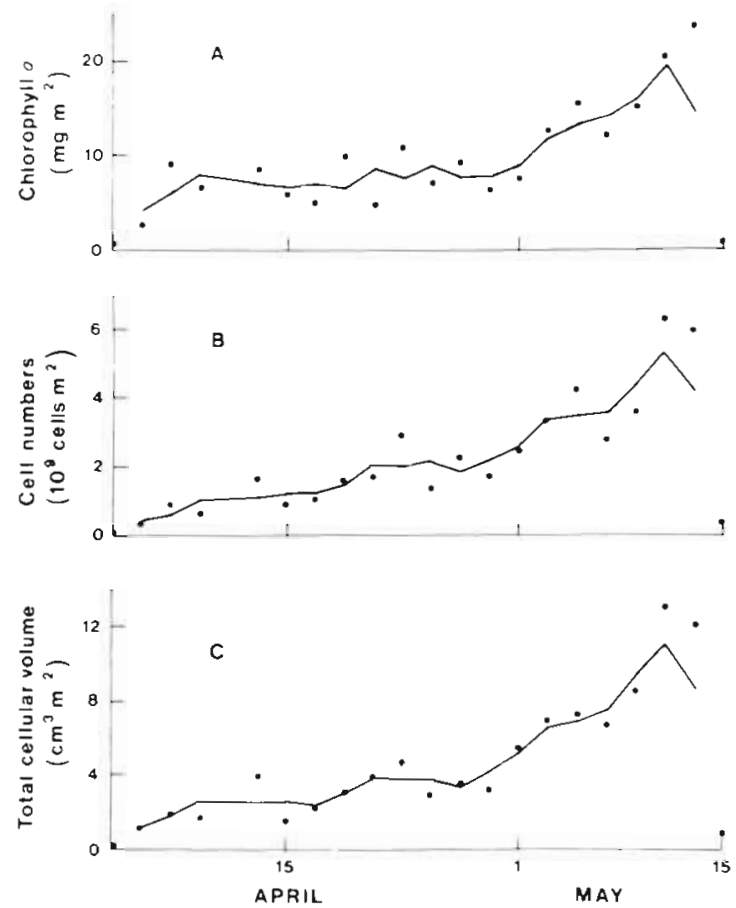

Fig. 3. Seasonal variations of (A) chlorophyll $a_{\text {, }}$ (B) cell numbers, and (C) total cellular volume. Observed data and moving average $(n=3)$

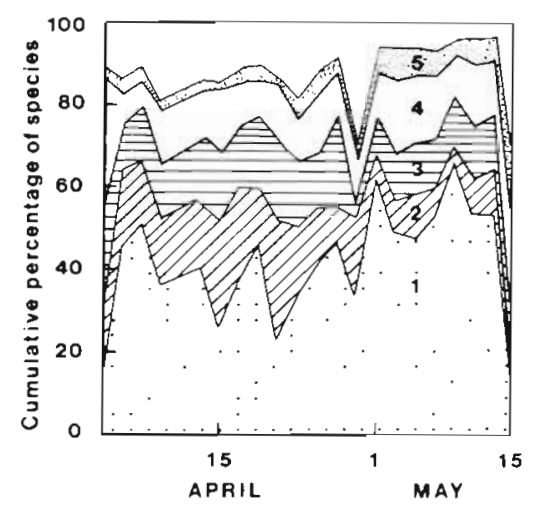

Fig. 4. Species composition of the sea-ice microalgal community at the ice-water interface: (1) Nitzschia frigida, (2) Nitzschia spp., (3) Navicula pelagica, (4) flagellates, and (5) Chaetoceros spp.

between $\mathrm{Iz}$ and $\mathrm{P}^{\mathrm{v}} \max$, even if this last parameter decreased at the beginning of the season (Fig. 6B) ( $\mathrm{r}=$ $0.80, p<0.01$ ). Photosynthetic efficiency, $\alpha^{\mathrm{b}}$ and $\alpha^{\mathrm{v}}$, had no seasonal trend, and did not respond to the rapid change in under-ice irradiance that occured on 25 April (Fig. 6C, D). The photoadaptive index (Ik) had clearly 2 different levels. Before 27 April it averaged 13.4 $\mu$ Ein $\mathrm{m}^{-2} \mathrm{~s}^{-1}(\mathrm{~s}=6.5)$, after which it increased to $29.5 \mu$ Ein $m^{-2} s^{-1}(s=17.7)$ (Fig. 6E); difference between the 2 means was significant ( $t$-test, $p<0.05)$. As in the cases
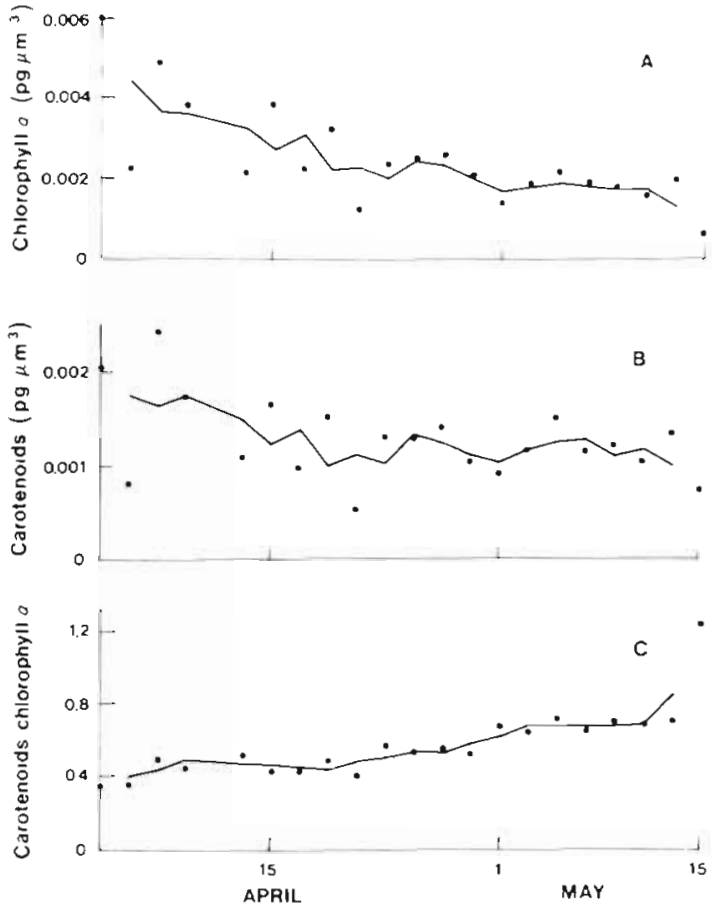

Fig. 5. Seasonal variations of (A) intracellular chlorophyll a, (B) intracellular carotenoids, and (C) carotenoids:chlorophyll a ratio. Observed data and moving average $(n=3)$

of $\mathrm{P}^{\mathrm{b}} \max$ and $\mathrm{P}^{\mathrm{v}} \max$, there was a $4 \mathrm{~d}$ lag between the changes in Ik and in the under-ice irradiance $(T=0.86$, $p<0.01)$. Finally, the photoinhibition parameter $\left(\beta^{\mathrm{b}}\right)$ dropped drastically on 25 April (Fig. 6F); $\beta^{v}$ (not shown) was almost the same as $\beta^{\mathrm{b}}$. Changes in photosynthetic parameters and enzyme activities normalized to cellular volume were not significantly correlated to changes of in situ temperature.

The activity of RuBPC ${ }^{b}$ increased seasonally (Fig. 7A) while the activities of $\mathrm{PePC}^{\mathrm{b}}, \mathrm{PePC}^{\mathrm{v}}$ and $\mathrm{PePCk}^{\mathrm{b}}$ (Fig. $7 B, C, E)$ did not show any definite seasonal trends. There were increased activities of $\mathrm{PePC}^{\mathrm{b}}$ and $\mathrm{PePC}^{\mathrm{v}}$ at the beginning and the end of the sampling season. On a volume basis, RuBPC activity had no seasonal trend but PePCk showed a slight decrease (Fig. 7B, F). Pmax was only correlated with RuBPC $(\mathrm{r}=0.86, p<0.01)$ and PePCk $(r=0.78, p<0.01)$. Finally, the seasonal increase of the ratio Pmax: carboxylating enzymes indicated a growing divergence between enzyme activities and the maximum photosynthetic rate (Fig. 8),

\section{DISCUSSION}

\section{Light and shade adaptation}

It has been shown (Falkowski 1980, 1981, Côté \& Platt 1984) that photoadaptation in phytoplankton is best characterized by the parameters of the photosyn- 

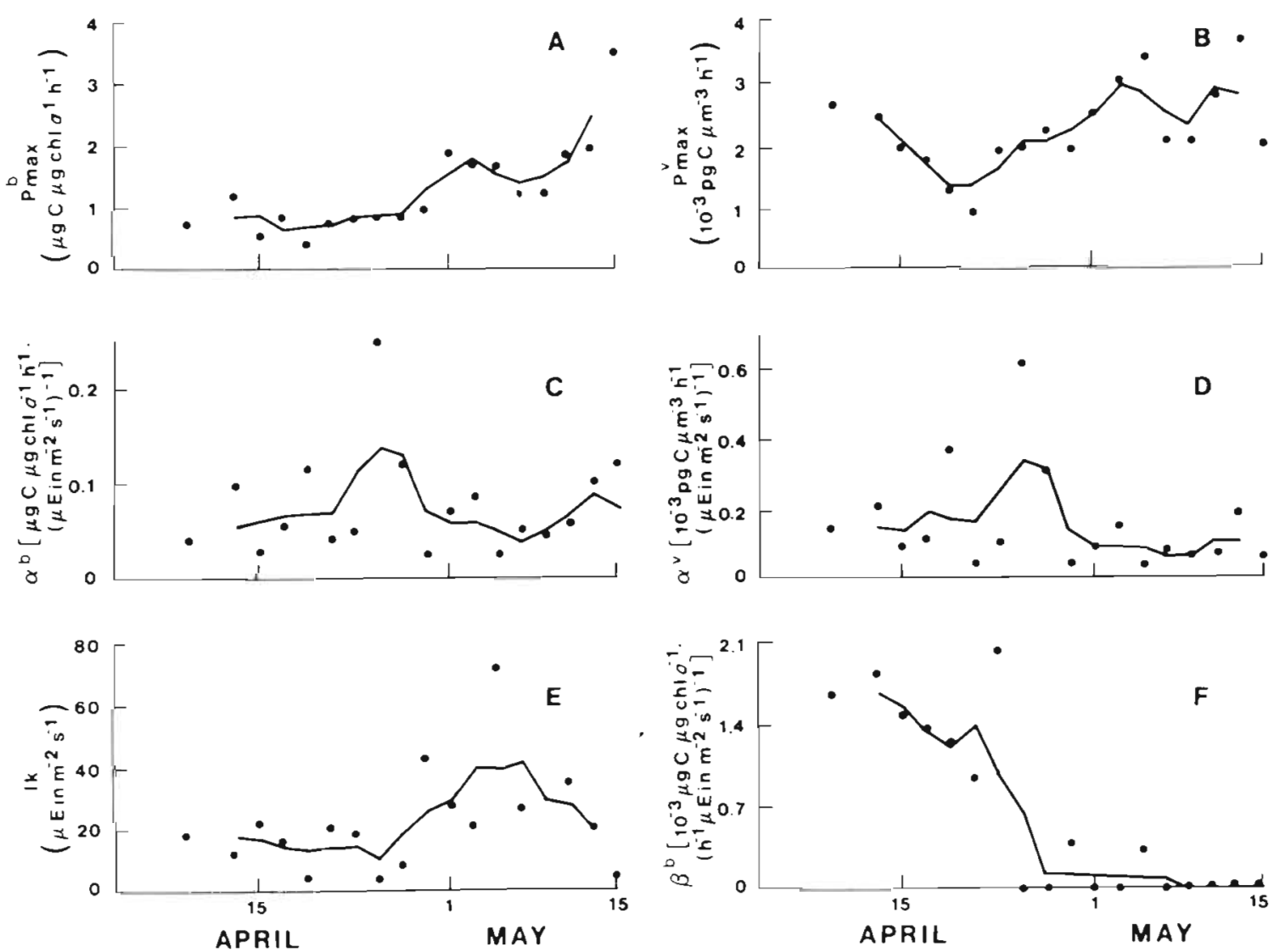

Fig. 6. Seasonal variations of the photosynthetic parameters. Maximum photosynthetic rate normalized (A) to chlorophyll a, and (B) to cellular volume; photosynthetic efficiency normalized (C) to chlorophyll $a$, and (D) to cellular volume; (E) photoadaptive index IK, and (F) photoinhibition parameter normalized to chlorophyll a. Observed data and moving average $(n=3)$

thesis versus irradiance curves, and especially the maximum rate of photosynthesis Pmax.

The rapid increase of under-ice irradiance on 25 April (Fig. 2A) clearly divided the growth season of ice algae in 2 distinct periods. Before 25 April, irradiance was very low $\left(<7 \mu\right.$ Ein $\left.\mathrm{m}^{-2} \mathrm{~s}^{-1}\right)$ and microalgae were characteristically shade-adapted, with low Pmax and Ik (Fig, 6A, B, E) and high cellular chlorophyll content as well as $\beta$ (Fig. 5A, 6F) (Steemann Nielsen \& Hansen 1959, Yentsch \& Lee 1966, Jørgensen 1969, Prézelin 1981, Falkowski \& Owens 1980, Perry et al. 1981). Two sets of observations can be used to identify mechanisms involved in this shade adaptation. First, the decrease of $\mathrm{P}^{\mathrm{v}} \max$ observed during this period (Fig. $6 \mathrm{~B}$ ) can be related to the decrease in cellular chlorophyll (Fig. 5A), suggesting that the maximum photosynthetic rate did depend on the trapping of light energy (Falkowski \& Owens 1980). Second, the fact that $\alpha^{v}$ did not follow the same trend as Pmax and cellular chlorophyll a implies that absorption of photons at low irradiance was not linked to an increased efficiency in the utilisation of light energy, thus suggesting possible limitation at the levels of either carboxylating reactions or elec- tron transport. The seasonal increase in the ratio Pmax : Scarboxylating enzyme activities (Fig. 8) indicates that carboxylating activity explained only part of the variations in maximum photosynthetic rate, as observed by several authors (Mukerji \& Morris 1976, Senger \& Fleishhacker 1978, Glover \& Morris 1979). It follows that enzyme activity, at low irradiances, was not the rate-limiting step of photosynthesis. This leaves the rate of electron transport, and also the trapping of light energy, as mentioned above, as the major control mechanisms of photosynthesis before 25 April.

After 25 April, ice algae adapted to the increased irradiance. This is shown by the rapid decrease in $\beta$ (Platt et al. 1980, Smith et al. 1983) and the increase $4 \mathrm{~d}$ later in $\mathrm{Ik}$, $\mathrm{P}^{\mathrm{b}} \max$ and $\mathrm{P}^{\mathrm{v}} \max$ (Fig. 6A, B, E, F) (Steemann Nielsen \& Hansen 1959, Steemann Nielsen \& Park 1964, Yentsch \& Lee 1966, Prézelin \& Sweeney 1978, Richardson et al. 1983, Palmisano et al. 1987). The first step of the photoadaptive response was a decrease in susceptibility to photoinhibition (decrease in $\beta, F i g .6 F)$, that occurred at the time of irradiance increase. This rapid response is in agreement with the results of Samuelsson \& Richardson (1982), who 

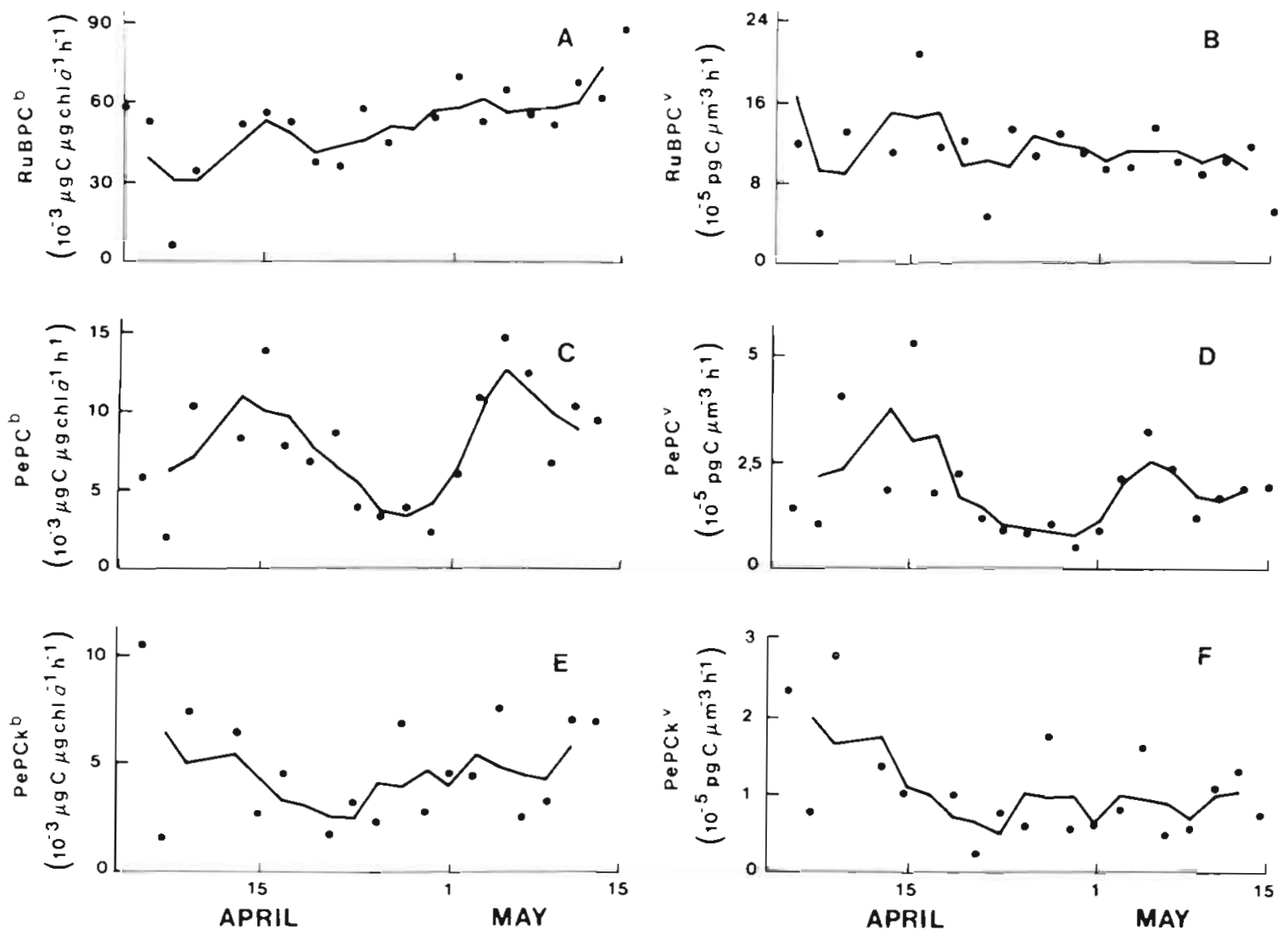

Fig. 7. Seasonal variations of enzyme activities. RuBPC normalized to (A) chlorophyll $a_{1}$ and (B) to cellular volume; PePC normalized (C) to chlorophyll $a$, and (D) to cellular volume; PePCk normalized (E) to chlorophyll a, and (F) to cellular volume. Observed data and moving average $(n=3)$

showed for Amphidinium carterae reversible photoinhibition within $2 \mathrm{~h}$ following an exposure to high irradiance. In their paper, the photoinhibitory response was a decrease of photosynthetic activity with exposure to high light; in the present study, photoinhibition is characterized by the slope $\beta$ of the inhibited portion of $\mathrm{P}$ vs I curves. This is not the same as in Samuelsson \& Richardson (1982), but changes in $\beta$ lead to a similar conclusion, which is that photoinhibition appears to be controlled by fast response mechanisms. Pmax and Ik also adjusted to the new

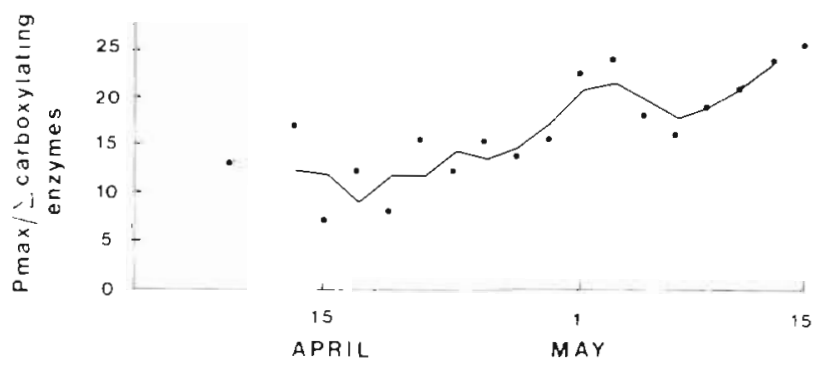

Fig. 8. Seasonal variations of the ratio of maximum photosynthetic rate to carboxylating enzyme activities. Observed data and moving average $(n=3)$ light conditions, but with a few days lag. This lag corresponds to cell division times, which varied from 2 to $23 \mathrm{~d}$ during the season and were about $4 \mathrm{~d}$ around 25 April (M. Gosselin unpubl.). Adaptation to higher irradiance took about one generation, contrary to photoinhibition response which was rapid.

After the ice algae had developed their light-adapted character (following 25 April), only $\mathrm{P}^{v}$ max continued to increase (Fig. 6A), while the cellular chlorophyll content remained constant (Fig. 5A) thus indicating the stability of the light-larvesting component. Moreover, the increase of the carotenoids: chlorophyll a ratio (Fig. $5 \mathrm{C})$ suggests that light energy absorbed by the cells exceeded their energetic requirements, since carotenoid pigments are known to provide photoprotection to chlorophyll $a$ by storing excess energy harvested by the cells (Prézelin 1981). As the under-ice irradiance increased, photosynthesis probably became limited only by the rate of electron transport. In that context, the augmentation of $\mathrm{P}^{\mathrm{b}} \max$ and $\mathrm{P}^{\mathrm{v}} \max$ with increasing light intensities (Fig. 6A, B) can be explained by a shortening of electron transport times, as shown by Barlow et al. (1988) for sea-ice microalgae at a nearby station in southeastern Hudson Bay. 


\section{Enzyme activities}

Carboxylating enzyme activities did not account for the total photosythetic capacity of ice-algae (Fig. 8). Values similar to those of Fig. 8 have been reported by Glover \& Morris (1979) who observed ratios Pmax: carboxylating enzyme activities up to ca 25 for natural phytoplankton. Other studies reported a contribution of carboxylating enzymes from less than $10 \%$ of photosynthesis (Mukerji \& Morris 1976) to $15 \%$ of the maximum photosynthetic rate (Smith et al. 1983).

In higher plants, changes in photosynthetic capacity have often been related to changes in carboxylating enzyme activities (Bjorkman 1968, Bowes et al. 1972, Blenkinsop \& Dale 1974). Concerning marine phytoplankton, Glover \& Morris (1979) reported increasing ratios of Pmax: carboxylating enzyme activities with higher Pmax. Also, Senger \& Fleishhacker (1978) observed that, whereas photosynthetic capacity of Scenedesmus obliquus tripled in high light, activity of RuBPC only doubled. These authors suggested that such changes could be interpreted as a partial limitation of photosynthetic capacity by dark enzyme reactions. The increasing ratio Pmax: $\Sigma$ carboxylating enzymes indicates that enzyme reactions explained a seasonally decreasing fraction of the maximum photosynthetic rate (Fig. 8). The high activity of RuBPC compared to PePC and PePCk clearly shows that $\mathrm{C}_{3}$ carboxylation dominated over $\beta$-carboxylations. This corresponds to data of Smith \& Platt (1985), who showed for Arctic phytoplankton that RuBPC was the only enzyme tightly linked to photosynthetic capacity. For marine phytoplankton, Appleby et al. (1980) and Descolas-Gros \& Fontugne (1985) observed that RuBPC dominated over the PePC and PePCk. Descolas-Gros \& Fontugne (1985) also showed that PePC and PePCk never occurred simultaneously in the same algal species, PePC being found in flagellates and PePCk in diatoms. The simultaneous activities of PePC and PePCk measured in ice algae was probably due to the species composition of the ice community, which comprised both diatoms and flagellates (Fig. 4). Also, the increased activity of $\mathrm{PePC}$ at the beginning and at the end of the sampling season (Fig. 7C, D) may be related to increased proportions of flagellates at these periods (Fig. 4). The fact that only RuBPC and PePCk were correlated with the maximum photosynthetic rate supports the view that PePCk, rather than PePC, is active in diatoms that dominate the ice-algal biomass.

Photoadaptive processes have been proved to be important for both Arctic and Antarctic algae (Palmisano \& Sullivan 1982, Gosselin et al. 1985, Palmisano et al. 1986, 1987, Sakshaug \& Holm-Hansen 1986). Our results support these findings and emphasize the view that the ability of sea-ice microalgae to photoadapt as the under-ice irradiance seasonally increases contribute to their high productivity in springtime and early summer.

Acknowledgements. This research was funded by the Natural Sciences and Engineering Research Council of Canada (strategic and individual research grants to L. L.), by the Maurice-Lamontagne Institute (Department of Fisheries and Oceans) and by grants to GIROQ from the Fonds FCAR of Québec and NSERC. The first author (C. M.) received a postgraduate scholarship from the Fonds FCAR, and financial support from the Department of Indian and Northern Affairs for field work. Helicopter time was provided by Fisheries and Oceans. Housing was at the Kuujuarapik field station of the Centre d'études nordiques, Université Laval, where we benefited from the invaluable assistance of the superintendent $C$. Côté. We are especially indebted to C. Corbeil for laboratory assistance, P. Jalbert for cell enumeration, E. Bonneau, M. Dubé, and P. Joly for field assistance, the SCUBA divers for under-ice sampling, K. Shirasawa for providing the physical data, and 4 reviewers for their most useful suggestions.

\section{LITERATURE CITED}

Appleby, G. J., Colbeck, E., Holdsworth, S., Wadman, H. (1980). Carboxylating enzymes in marine phytoplankton and isolation and purification of pyruvate carboxylase from Amphidinium carterae (Dinophyceae). J. Phycol. 16: 290-295

Appolonio, S. (1961). The chlorophyll content of Arctic sea-ice. Arctic: $14: 197-200$

Appolonio, S. (1965). Chlorophyll in Arctic sea-ice. Arctic 18: 118-122

Barlow, R. G., Gosselin, M., Legendre, L., Therriault, J.-C., Demers, S., Llewellyn, A., Mantoura, R. F. C. (1988). Photoadaptive strategies in sea-ice microalgae. Mar. Ecol. Prog. Ser. 45: 145-152

Beardall, J., Morris, I. (1976). The concept of light intensity adaptation in marine phytoplankton: some experiments with Phaeodactylum tricornutum. Mar. Biol. 37-377-387

Berry, J., Björkman, O. (1980). Photosynthetic response and adaptation to temperature on higher plants. Ann. Rev. Plant. Physiol. 31: 491-543

Berry, J., Raison, J. K. (1981). Responses of macrophytes to temperature. In: Lange, P. L., Nobek, P. S., Osmond, C. B., Ziegles, H. (eds.) Physiological plant ecology I. Responses to the physical environment. The encyclopedia of plant physiology, Vol. 12A, new ser. Springer, Berlin, p. 277-338

Björkman, O. (1968). Carboxydismutase activity in shadeadapted and sun-adapted species of higher plants. Physiol. Plant. 21: 1-10

Blenkinsop, P. G., Dale, J. E. (1974). The effect of shade treatment and light intensity on ribulose-1,5-diphosphate carboxylase activity and fraction I protein level in the first leaf of barley. J. exp. Bot. 25: 899-912

Bowes, G., Ogren, W. L., Hageman, R. H. (1972). Light saturation, photosynthesis, RuDP carboxylase activity, and specific leaf weight in soybeans grown under different light intensities. Crop Sci. 12: 77-79

Bunt, J. S. (1968). Some characteristics of microalgae isolated from Antarctic sea-ice. Antarct. Res. Ser. 1. 1-14

Bunt, J. S., Lee, C. C. (1970). Seasonal primary production in Antarctic sea-ice at Mc Murdo Sound in 1967. J. mar. Res. 28: $304-320$ 
Cota, G. F. (1985). Photoadaptation of high arctic algae Nature, Lond. 315: 219-222

Côté, B., Platt, I (1984). Utility of the light-saturation curve as an operational model for quantifying the effects of environmental conditions on phytoplankton photosynthesis. Mar Ecol. Prog Ser 18: 57-66

Descolas-Gros, C., De Billy, G. (1987). Temperature adaptation of RuBP carboxylase: kinetic properties in marine Antarctic diatoms. J. exp. mar. Biol. Ecol. 108: 147-158

Descolas-Gros, C., Fontugne, M. R. (1985). Carbon fixation in marine phytoplankton: carboxylases activities and stable carbon-isotope ratios; physiological and paleoclimatological aspects. Mar. Biol. 87: 1-6

Falkowski, P. G. (1980). Light-shade adaptation in marine phytoplankton. In: Falkowski, P. G. (ed.) Primary productivity in the sea. Plenum Press, New York, p. 99-119

Falkowski, P. G. (1981). Light-shade adaptation and assimilation numbers. J. Plankton Res. 3: 203-216

Falkowski, P. G., Owens, T. G. (1980). Light-shade adaptation: Two strategies in marine phytoplankters. Plant Physiol. 66 : 592-595

Glover, H. E., Morris, I. (1979). Photosynthetic carboxylating enzymes in marine phytoplankton. Limnol. Oceanogr 24 (3): 510-519

Gosselin, M., Legendre, L., Demers, S., Ingram, R. G. (1985). Responses of sea-ice microalgae to climatic and fornightly tidal energy inputs (Manitounuk Sound, Hudson Bay) Can. J. Fish. Aquat. Sci. 42 (5): 999-1006

Horner, R. A., Schrader, G. C. (1982). Relative contributions of ice algae, phytoplankton and benthic microalgae to primary production in nearshore regions of the Beaufort sea. Arctic 35: 485-503

Jacques, G. (1983). Some ecophysiological aspects of the Antarctic phytoplankton. Polar Biol. 2: 27-33

Jeffrey, S. W., Humphrey, G. F. (1975). New spectrophotometric equations for determining chlorophylls $a, b, c_{1}$ and $c_{2}$ in higher plants, algae and natural phytoplankton. Biochem. Physiol. Pflanz. 167: 191-194

Jorgensen, E. G. (1969). The adaptation of planktonic algae. IV. Light adaptation in different species. Physiol. Plant 22 $1307-1315$

Legendre, L., Demers, S., Yentsch, C. M., Yentsch, C. S. (1983). The $\mathrm{C} 14$ method patterns of dark $\mathrm{CO}_{2}$ fixation and DCMU correction to replace the dark bottle. Limnol. Oceanogr. 28: 996-1003

Lewis, M. R., Smith, J. C. (1983). A small volume, shortincubation-time-method for measurement of photosynthesis as a function of incident irradiance. Mar. Ecol. Prog. Ser. 13: 99-102

Li, W K. W., Smith, J. C., Platt, T (1984). Temperature response of photosynthetic capacity and carboxylase activity in Arctic marine phytoplankton. Mar. Ecol. Prog. Ser. 17: $237-243$

Lund, J. W. G., Kipling, C., Le Cren, E. D. (1958). The inverted microscope method of estimating algal numbers and the statistical basis of estimations by counting. Hydrobiologia 11: $143-170$

Maykut, G. A., Grenfell, T C. (1975). The spectral distribution of light beneath first year sea-ice in the Arctic ocean. Limnol. Oceanogr 20: 554-563

Meguro, H., Kuniyuki, I., Fukushima, H. (1967). Ice flora (bottom type): a mechanism of primary production in the polar seas and the growth of diatoms in sea ice. Arctic 20: $114-133$

Miller, M. R., Castellot, J. J. Jr, Pardee, A. B. (1978). A permeable animal cell preparation for studying macromolecular synthesis. DNA synthesis and the role of desoxyribonucleotides in S phase initiation. Biochemistry, N.Y 17: 1073-1080

Miller, M. R., Castellot, J. J. Jr, Pardee, A. B. (1979). A general method for permeabilizing monolayer and suspension cultured animals cells. Exp. Cell Res. 120: 421-425

Mukerji, D., Morris, I. (1976). Photosynthetic carboxylating enzymes in Phaeodactylum tricornutum: assay methods and properties. Mar. Biol. 36: 199-206

Neori, A., Holm-Hansen, O. (1982). Effect of temperature on rate of photosynthesis in Antarctic phytoplankton. Polar Biol. 1: 33-38

Palmisano, A. C., Sullivan, C. W. (1982). Physiology of sea-ice diatoms. I. Response of three polar diatoms to a simulated summer-winter transition. J. Phycol. 18: 489-498

Palmisano, A. C., SooHoo, J. B., Sullivan, C. W. (1985). Photosynthesis irradiance relationship in sea-ice microalgae from Mc Murdo Sound Antarctica. J. Phycol. 21: 341-346

Palmisano, A. C., SooHoo, J. B., SooHoo, S. L., Kottmeier, S. T., Lin, L. C., Sullivan, C. W. (1986). Photoadaptation in Phaeocystis pouchetii advected beneath annual sea-ice in Mc Murdo Sound, Antarctica. J. Plankton Res. 8 (5): $891-906$

Palmisano, A. C., SooHoo, J. B., Sullivan, C. W. (1987). Effects of four environmental variables on photosynthesisirradiance relationships in Antarctic sea-ice microalgae. Mar. Biol. 94: 299-306

Perry, M. J., Larson, M. C., Alberte, R. S. (1981). Photoadaptation in marine phytoplankton: responses of the photosynthetic unit. Mar. Biol. 62: 91-101

Platt, T., Gallegos, C. L., Harrison, W. G. (1980). Photoinhibition of photosynthesis in natural assemblages of marine phytoplankton. J. mar. Res. 38 (4): 687-701

Prézelin, B. B. (1981). Light reactions in photosynthesis. In Platt, T. (ed.) Physiological basis of phytoplankton ecology. Can. Bull. Fish. Aquat. Sci. 210: 1-43

Prézelin, B. B., Sweeney, B. M. (1978). Photoadaptation of photosynthesis in Gonyaulax polyedra. Mar. Biol. 48 $27-35$

Richardson, K., Beardall, J., Raven, J. A. (1983). Adaptation of unicellular algae to irradiance: an analysis of strategies. New Phytol. 93: 157-191

Rochet, M., Legendre, L. Demers, S. (1986). Photosynthetic and pigment responses of sea-ice microalgae to changes in light intensity and quality. J. exp. mar Biol. Ecol. 101 211-226

Saksaugh, E., Holm-Hansen, O. (1986). Photoadaptation in Antarctic phytoplankton: variations in growth rate, chemical composition and $\mathrm{P}$ versus I curves. J. Plankton Res. 8 (3): $459-473$

Samuelsson, G., Richardson, K. (1982). Photoinhibition at low quantum flux densities in a marine dinoflagellate (Amphidinium carterae). Mar. Biol. 70: 21-26

Senger, H., Fleishhacker, P. H. (1978). Adaptation of the photosynthetic apparatus of Scenedesmus obliquus to strong and weak light conditions. I. Differences in pigments, photosynthetic capacity, quantum yield and dark reactions. Physiol. Plant. 43: 35-42

Smayda, T G. (1978). From phytoplankters to biomass. In Sournia, A. (ed.) Phytoplankton manual. Monographs on oceanographic methodology. Vol 6. p. 273-279

Smith, J. C., Platt, T (1985). Temperature responses of ribulose biphosphate carboxylase and photosynthetic capacity in arctic and tropical phytoplankton. Mar Ecol. Prog. Ser. 25: $31-37$

Smith, J. C., Platt, T., Harrison, W. G. (1983). Photoadaptation of carboxylating enzymes and photosynthesis during a spring bloom. Prog. Oceanogr 12: 425-459 
Steemann Nielsen, E., Hansen, V K. (1959). Light adaptation in marine phytoplankton populations and its interrelation with temperature. Physiol. Plant. 12: 353-372

Steemann Nielsen, E., Park, T. S. (1964). On the time course in adapting to low light intensities in marine phytoplankton J. Cons. perm. int. Explor. Mer 29 (1): 19-24

Storro, I., Mc Fadden, B. A. (1983). Ribulose biphosphate carboxylase oxygenase in toluene-permeabilized Rhodospirillum rubrum. Biochem. J. 212: 45-54
Syrett, P. J. (1973). Measurement of nitrate-and-nitrite-reductase activities in whole cells of Chlorella. New Phytol. 72 : $37-46$

Talling, J. F. (1957). Photosynthetic characterization of some freshwater plankton diatoms in relation to underwater radiation. New Phytol. 56: 29-50

Yentsch, C. S., Lee, R. W (1966). A study of photosynthetic light reactions and a new interpretation of sun and shade phytoplankton. J. mar Res. 24:319-337

This article was submitted to the editor; it was accepted for printing on September 24, 1988 